Military Technical College

Kobry El-Kobbah, Cairo, Egypt.

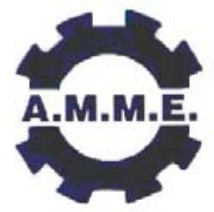

$13^{\text {th }}$ International Conference on Applied Mechanics and Mechanical Engineering.

\title{
ACOUSTIC PROPERTIES OF SOUND ABSORPTION PANELS USING MULTI-LAYER COIR FIBERS
}

\author{
ZULKIFLI R., NOR ${ }^{* *}$ M.J.M., MAT TAHIR ${ }^{* * *}$ F. and ISMAIL ${ }^{* * *}$ A.R.
}

\begin{abstract}
The aim of the project was to study the potential use of an innovative acoustic absorption panel using natural organic fiber as an absorbing materials to reduce reverberation effect in closed spaces and to improve the acoustics performance of an enclosed space. This innovative acoustic absorption panel is developed and fabricated using treated coir fiber as sound absorber materials. The outer layer of the panel is fabricated from natural fiber/polyester composite. This innovative panel was tested at acoustic lab, faculty of engineering, Universiti Kebangsaan Malaysia using ISO 354 (1985) standard for noise absorption coefficient and ISO 717-1 Standard for the transmission lost index. Simulation study was also conducted for the absorption panel using the WinFLAG ${ }^{\mathrm{TM}}$ software. For the absorption coefficient, the experiment gives around $0.70-0.80$ from the range $1000 \mathrm{~Hz}$ until $1800 \mathrm{~Hz}$ while the simulation gives 0.7 until 0.85 for the range $500 \mathrm{~Hz}$ until $2500 \mathrm{~Hz}$. Transmission lost index gives an average of $20 \mathrm{~dB}$ for the panel.
\end{abstract}

\section{KEY WORDS}

Acoustic materials, coir fiber, noise absorption coefficient, transmission lost index.

\footnotetext{
* Senior Lecturer, ${ }^{* *}$ Professor, ${ }^{* * *}$ Tutor, ${ }^{* * * *}$ Lecturer, Department of Mechanical \& Materials Engineering, Universiti Kebangsaan Malaysia.
} 


\section{INTRODUCTION}

In Malaysia, agriculturals waste such as coconut fibers (Cocos nucifera), rice fiber (Oryza sativa) and oil palm frond fiber (Elaeis Guinnesis) are abundance and usually burnt or used as an agricultural by-products. Recently, natural fibers from agriculture are increasingly being investigated for various usage in many structural and nonstructural applications such as a substitute for synthetic fibers in composite materials and lining for automotive components. However, natural fibers such as coir fiber are also suitable as a substitute to synthetic fibers and wood-based materials for acoustic absorption purposes. These fibers have many advantages because they are cheaper, renewable and abundance, non-abrasive and does not give rise to health and safety issue during processing and handling [1-4].

The aim of this project was to study the potential use of the multi-layer coir fibers as a sound absorption material. This paper investigated the sound absorption properties of the coir fibers together with the characteristics of the coir fibers and its fiber arrangement. The main parameter that is critical in the determination of the acoustic properties is the acoustic absorption coefficient properties and these parameters were determined using the tests carried out in the reverberation room. Computer simulation using the dBBAT132 program was carried out to determine the acoustic parameters. The acoustic properties of the rock wool materials were also determined as a comparison. The effect of the airspace layers in the coir fibers to the acoustic properties were analyzed in order to determine the relationship between them. The fibers arrangements in the plate were studied using the scanning electron microscope. Latex are used to provide the necessary cohesion between the coir fibers so that its arrangement can be moulded into square layers for the acoustic testing purposes. The latex was shown to have no influence on the sound absorption properties due to the small influence on the fibers physical characteristics. The results of the acoustic properties obtained shows that the coir fibers gave a good sound absorption coefficient as compared to the commercial sound absorption materials such as rock wool. The fibers arrangement in the coir fiber can be modified in order to control the sound absorption properties. This will allow the coir fibers to be used in applications to reduce sound propagation in interior spaces or to improve the control of outdoor noise propagation [5-7].

\section{EXPERIMENTAL METHODS AND MATERIALS}

There are two main parts in carrying out this research. The first is to fabricate the composite panel box using coir/polyester composites and the second is to use treated coir fiber as the filler. The combination of high quality natural fiber/polyester composite and coir fiber filler give the panel a good absorption characteristic. Fabricated with polyester resin and metal-etil-cethone-peroxside as a catalyst for the matrix and reinforced with coir fiber make the composite strong and good enough for physical performance Perforated panel design requires holes to be drilled on the panels surface in order to give more advantages in acoustic part by decreasing the optimum absorption coefficient to the lower frequency [8].

Some of the experiment equipment is calibrator $94.0 \mathrm{~dB}, 100 \mathrm{~Hz}$ (Cal $2101 \mathrm{~dB}$ ), microphones (GRAS 26 AK), speaker, amplifier and symphony (Dual-Channel Real Time Acquisition Unit). The test was also simulated using DBBATI32 software. 


\section{TESTING}

\section{Noise Absorption Coefficient}

\section{a) Experiments Using Reverberation Room}

Experiments using the reverberation room have been performed to calculate the noise reduction coefficient (NRC). The test was performed using ISO 354 (1985) standard for noise absorption coefficient. The required inputs are reverberation time for empty room, RT0 and reverberation time for room with sample, RTm. Parameter needed for the experiment are volume for an empty reverberation room and testing area for the sample. Figure 1 shows the schematic drawing of the experimental setup and figure 2 shows the sound absorption panel using coir fiber as the absorption material.

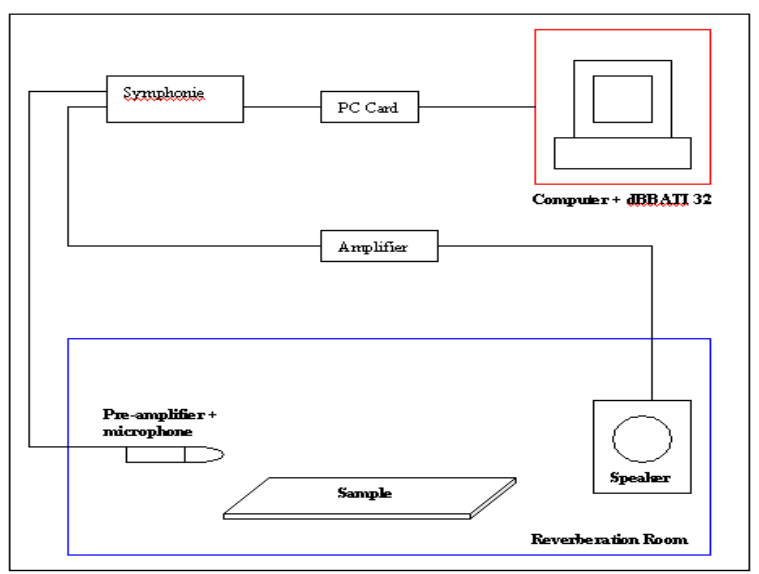

Fig. 1. Schematic configuration of reverberation room.
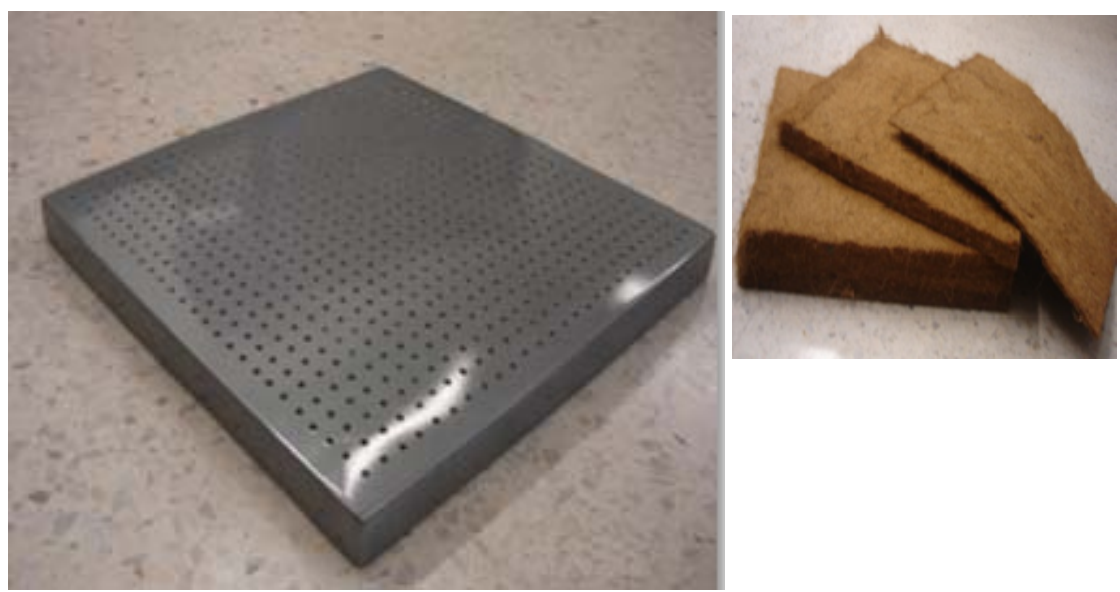

Fig. 2. Sound Absorption Panel using coir fiber as an absorption material. 


\section{b) Simulation by WinFLAGTM Program}

For the simulation works, absorption coefficients of panels were calculated by the computer WinFLAGTM, developed at NTNU. This program implements the transfer matrix method for a number of materials, including porous material and perforated plates (slotted, with circular holes etc). The program calculates the absorption coefficient, impedance and sound reduction index. Calculation can be performed at single frequencies or as mean values in $1 / 3$ octave band.

\section{Transmission Lost}

Experiments for the transmission lost have been conducted at acoustic lab, which consisted of reverberation room and semi anechoic chamber using the ISO 717-1 standard [9]. The composite panel was placed between the two rooms and a noise source was given from the reverberation room. One microphone was placed at semi anechoic chamber to receive the sound that has been transmitted. The data was analyzed to determine the transmission loss value. Figure 3 and 4 show the setup for the transmission lost test.

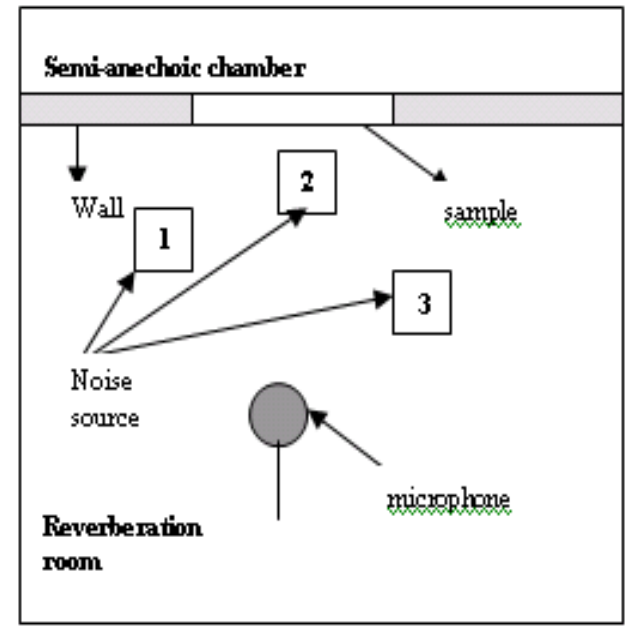

Fig. 3. Figure shows the location for the source before run the test

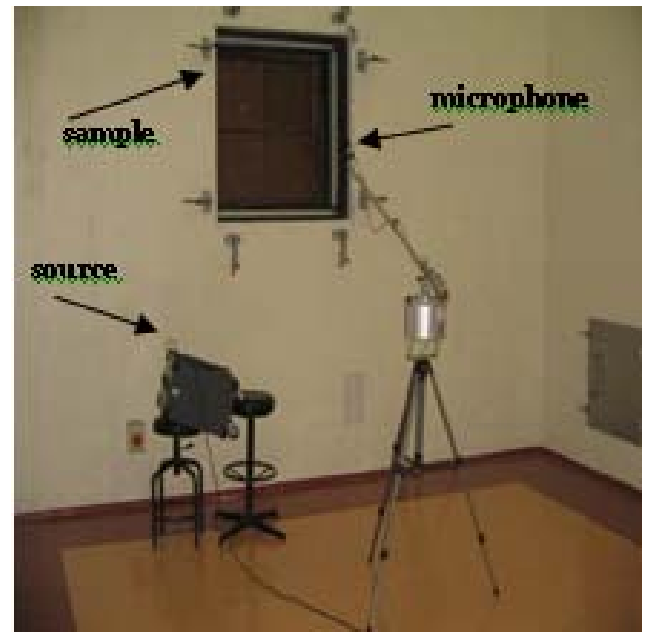

Fig. 4. Figure shows the equipment location for the test.

\section{RESULTS AND DISCUSSIONS}

\section{Noise Absorption}

Simulations have been conducted before the experiment to give some figure on what will happen. The simulation for the noise absorption coefficient of the plain coir fiber and coir fiber with perforated panel was calculated. Figure 5 shows the result for the noise absorption coefficient. The coir fiber panel has higher coefficient index compared to the plain coir fiber for the range of $500 \mathrm{~Hz}$ until $2500 \mathrm{~Hz}$. For the frequency range of more than $2500 \mathrm{~Hz}$, the plain coir fiber has higher coefficient index. The highest coefficient index for coir fiber with perforated panel is in the range of 0.7 to 0.85 for the frequency 
range of $500 \mathrm{~Hz}$ until $2500 \mathrm{~Hz}$. For the coir fiber only is around 0.8 for the range 2500 $\mathrm{Hz}$ until $5000 \mathrm{~Hz}$.

The experimental results are found to be similar to the simulation results. Figure 6 shows the experimental result of the noise absorption coefficient. The coir fiber with the perforated panel gives higher value for the lower frequencies range from $800 \mathrm{~Hz}$ until $1800 \mathrm{~Hz}$. Higher than that, the coir fiber give much higher value. The optimum value for coir fiber with perforated panel is around $0.70-0.80$ for the frequency range of $1000 \mathrm{~Hz}$ to $1800 \mathrm{~Hz}$ and the plain coir fiber is 0.78 for $2000 \mathrm{~Hz}$ frequency.

Ballagh [10] found that the noise coefficient increases with the smaller fiber diameter. With the impermeable size much smaller compare to sound wavelength, the change from the sound energy to heat energy will increase because of friction air particle that vibrate. Other parameters such as porosity and tortuosity are included to define the acoustic properties for impermeable material.

By using the perforated panel, it has transfer the noise absorption coefficient peak to the lower frequency but decrease the coefficient for much higher frequency. Theoretically, when a perforated plate has an air gap, an air cell system can be assumed for every imaginary air cell behind each hole under the plate. The phenomenon is known as the Hemholtz resonator. Based on the study on the effect of using impermeable material behind the perforated plate, Lee and Chen [9] found that the impermeable material increasing the noise absorption coefficient and decrease the resonance frequency to the lower frequency range [9].

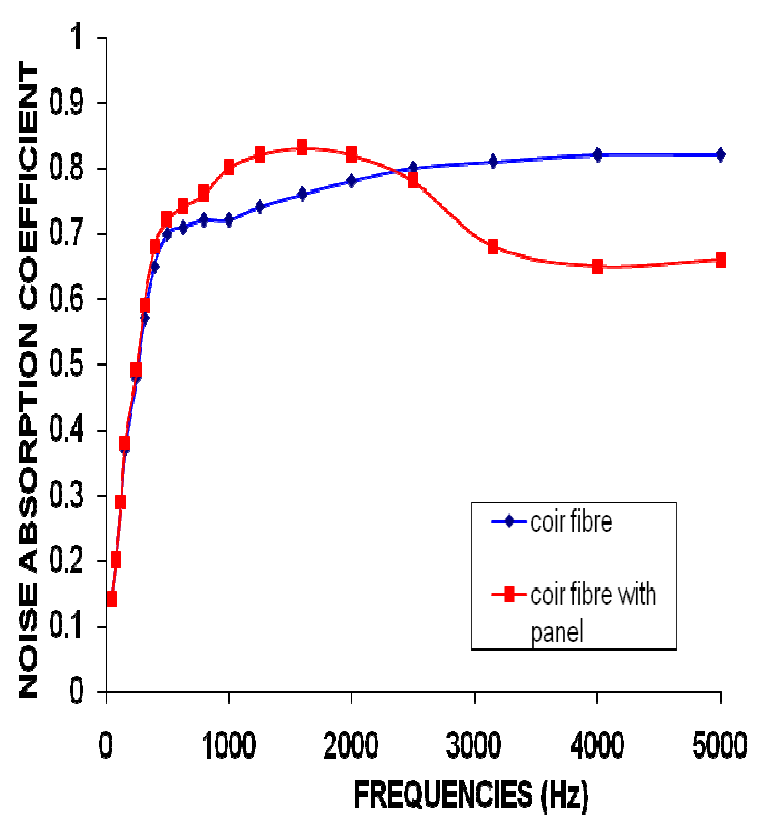

Fig. 5. Comparison of simulation results for noise absorption coefficient between plain coir fiber and coir fiber panel

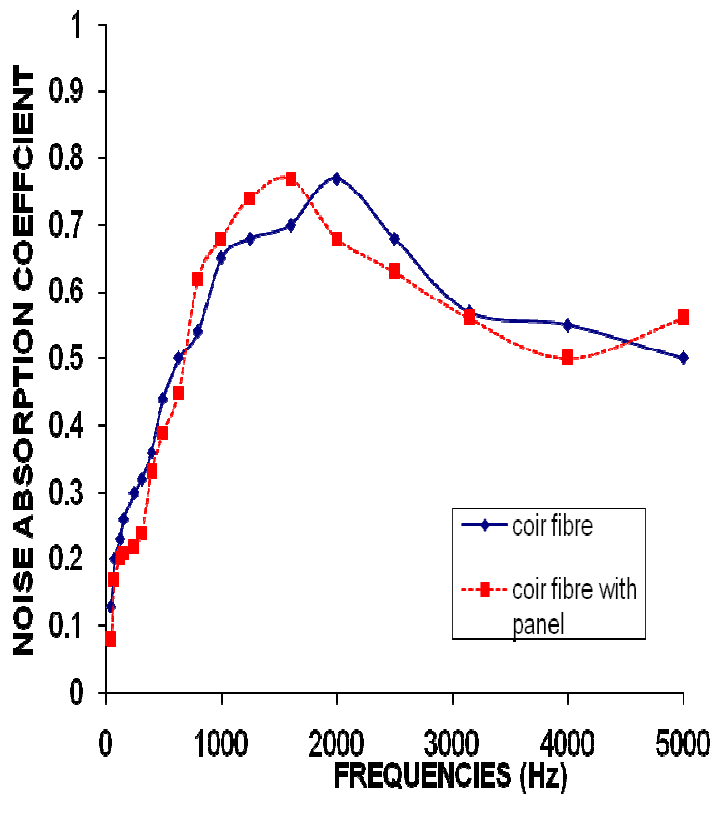

Fig. 6. Comparison of experimental results for noise absorption coefficients between plain coir fiber and coir fiber panel 


\section{Transmission Loss}

The experimental results of the transmission loss index for the composite panel box have an average value of $20 \mathrm{~dB}$. Several other tests have also been carried out to compare the results. Figure 7 shows the result of transmission lost index versus frequency. Graph 8 shows the comparison for several other type of panel box composite. For the first 12 data point, the composite panel with coir fiber gives the comparable transmission lost index compare to other samples. Beginning from no.12 to 16, for the range of $630 \mathrm{~Hz}$ until $1600 \mathrm{~Hz}$, the composite gives higher value of transmission lost index compared to the curve for composite with coir fiber without closed panel and from no. 17 until 27, it is giving the highest transmission lost index compared to the others.

Composite with oil palm fiber sample shows the optimum value from the 6th data (160 $\mathrm{Hz}$ ) until 8th data $(315 \mathrm{~Hz})$. For the forth sample (with coir fiber/without closed panel) the optimum value for transmission lost index appears from the range 16th data $(1600 \mathrm{~Hz})$ until 24th data $(10 \mathrm{kHz})$.

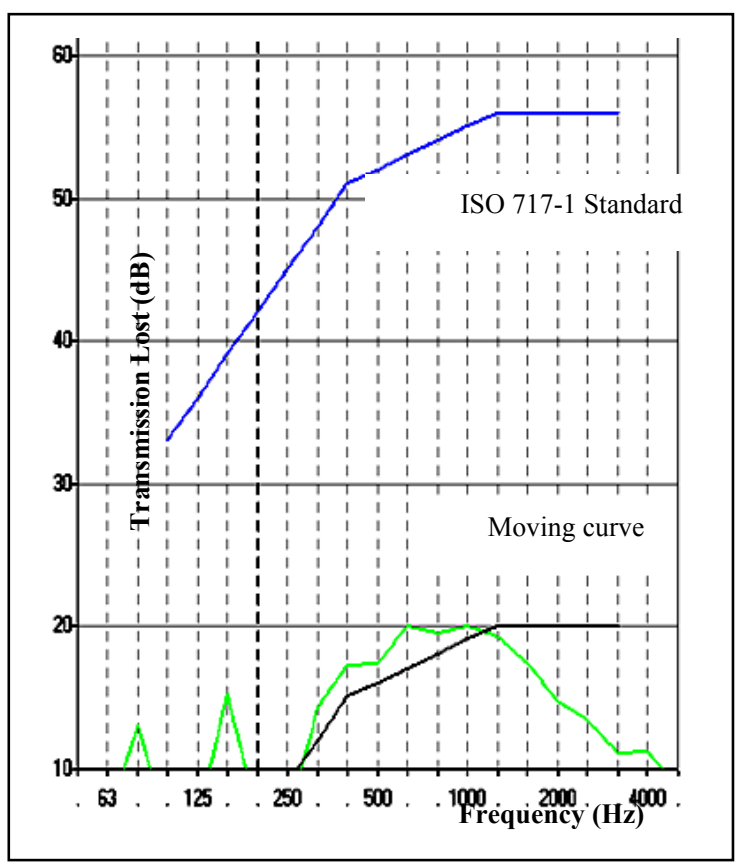

Fig. 7. Transmission lost index versus frequency

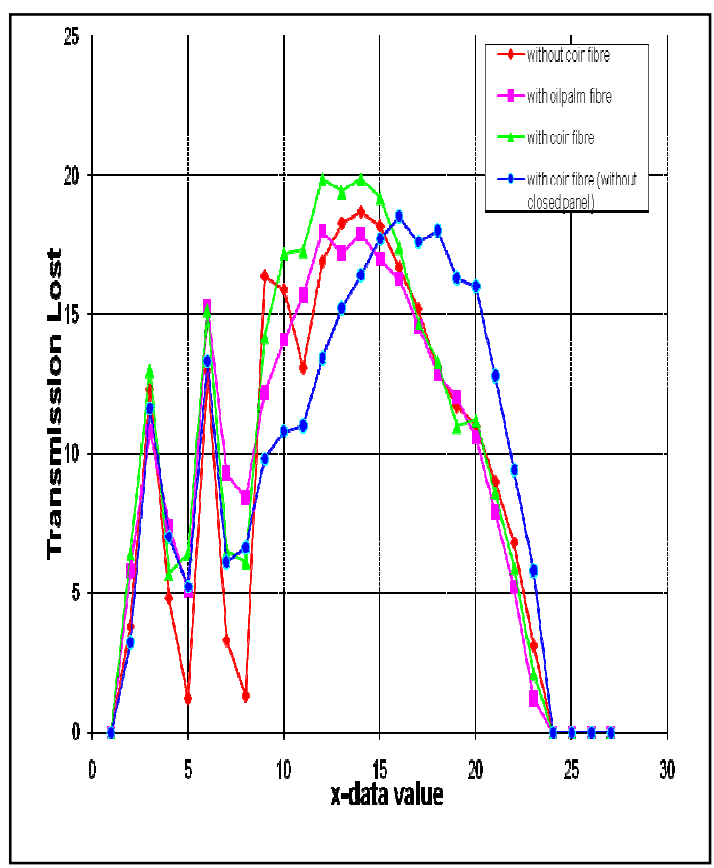

Fig. 8. Comparison of transmission lost index versus data value for different configuration of coir fiber

\section{CONCLUSION}

In this work coir fiber has been introduced as one of the noise absorption material. The results form the simulation and experimental test show that it has a good potential to perform like the commercialize product. By introducing the composite made from fiberreinforced polymeric materials, the noise absorption panel shows a good potential as one of the environmentally friendly product. As one of the green technology product, this innovative absorption panel has a bright future because they are cheaper lighter 
and environmentally superior compare to glass fiber composite. However a lot of works have to be carried out in the future to optimize and increases the performance of the coir fibers.

\section{REFERENCES}

[1] Wambua, P., Ivens, J. and Verpoest, I., "Natural Fibers: Can They Replace Glass in Fiber Reinforced Plastics?", Composites Science and Technology, Vol. 63, pp 1259-1264, (2003).

[2] Joshi, S.V., Drzal, L.T., Mohanty, A.K. and Arora, S., "Are Natural Fiber Composites Environmentally Superior to Glass Fiber Reinforced Composites?", Composites: Part A, Vol. 35, pp 371-376, (2004).

[3] Khedari, J., Charoenvai, S. and Hirunlabh, J., "New insulating particleboards from durian pee and coconut coir", Building and Environment, Vol. 38, pp 435441, (2003).

[4] Mohd Nor, M.J., Jamaludin, N. and Mohd Tamiri, F., "A Preliminary Study of Sound Absorption Using Multi-Layer Coconut Coir Fibers", Electronic Journal $<$ Technical Acoustics> http://webcenter.ru/ eeaa/ejta, (2004).

[5] Mohd Tamiri, F., "Semi-Active noise absorption composite panel using natural fiber", Master Thesis, Universiti Kebangsaan Malaysia, (2006).

[6] Wang, C.N., Kuo, Y.M. and Chen, S.K., "Effects of compression on the sound absorption of porous materials with an elastic frame", Applied Acoustics, doi: 10.1016/j.apacoust.2006.08.006, (2006).

[7] Larbig, H., Scherzerr, H., Dahlke, B. and Poltrock, R., "Natural Fiber reinforced foams based on renewable resources for automotive interior applications", Journal of Cellular Plastics, Vol. 34, pp 361-79, (1998).

[8] Jinkyo, L. \& Swenson G.W., "Compact Sound Absorbers for Low Frequencies", Noise Control Engineering Journal, Vol. 38(3), pp 109-117, (1992).

[9] Lee, F.-C. \& Chen, W.-H., "Acoustic Transmission analysis of multi-layer absorbers", Journal of Sound and Vibration, Vol. 4, pp 621-634, (2001).

[10] Ballagh, K.O., "Acoustical properties of wool", Applied Acoustics, Vol. 48(2), pp 101-120, (1996). 